\title{
SOCIOECONOMIC FACTORS AND CHANGES IN FOOD CHOICE AND AVAILABILITY DURING COVID-19 RESTRICTIONS IN LATVIA
}

\author{
leva Pitkēviča\#, Elizabete Pumpure, Marta Laura Graviṇa, Darja Mihailova, leva Briedīte, \\ Dace Rezeberga, Ināra Kantāne, Anda Ķīvīte-Urtāne, and Gunta Lazdāne
}

Rīga Stradinš University, 16 Dzirciema Str., Rīga, LV-1007, LATVIA

\# Corresponding author, ievapitkevica@gmail.com

Communicated by Aivars Lejnieks

\begin{abstract}
The COVID-19 pandemic changed the life of many. The study aimed to identify fragile groups of the population regarding nutrition during the COVID-19 restriction period. An online survey was conducted from 26 July to 3 September 2020. A total of 1173 answers were received from persons aged 18-68 years living in Latvia. The results showed that food availability mainly was not limited, although for $15.3 \%$ responders restrictions caused increased worries about not having enough food, and $12.2 \%$ noted a decrease in the ability to eat preferred food. Responders aged 40-54 noted that they ate less, and that their food stocks were scarce in comparison with other age groups. Almost 50\% of responders increased food consumption. One-fifth of responders increased consumption of foods of low nutritional value, especially among 25-39 year old persons and in households where the economic situation became worse. Fragile groups regarding nutrition in times of COVID-19 restrictions included households whose economic situation became worse during the COVID-19 restrictions, younger people who increased food consumption together with consumption of food of low nutritional value, and persons aged 40-54 years. The data from the study serve as an indicator that more detailed research is needed to determine whether crises such as the COVID-19 pandemic are changing dietary habits and food availability in the population.
\end{abstract}

Keywords: pandemic, nutrition, resources.

\section{INTRODUCTION}

On 11 March 2020, the World Health Organisation declared COVID-19 as a pandemic caused by the novel coronavirus SARS-CoV-2 (WHO, 2020). The number of COVID-19 cases increased worldwide. In Latvia, the numbers of COVID-19 patients and fatalities were significantly lower per capita than in the neighbouring countries and globally. According to the Centre for Disease Prevention and Control of Latvia, the first COVID-19 case in Latvia was detected on 2 March. The incidence of COVID-19 during the study was low in comparison to many European countries. Until 3 September 2020, 1410 persons were detected COVID-19 positive, and for 34 persons the disease had already resulted in death (CDPC of Latvia, 2020).

Although the number of COVID-19 cases was lower compared with other countries, COVID-19 restrictions to limit the transmission rate of the virus, which took place from 12 March until 9 June 2020, were significant, including social distancing, self-isolation and quarantine, limited availability of services and everyday products and in some cases resulted in job loss. Restrictions affected people's lives, including their socioeconomic situation, the health and social care system, as well as the food supply system (Butler and Barrientos, 2020). During restrictions in Latvia, food stores were open and food supply was not disrupted.

In times of the COVID-19 pandemic, wider access to healthy food should be a necessity and top priority. Good overall health is essential for the prevention of infectious diseases. Obesity and type 2 diabetes are considered risk factors for more a severe form of COVID-19 disease and mortality (Dietz and Santos-Burgoa, 2020). Unhealthy nutrition is an important pathogenic factor for both of these 
health conditions. The high prevalence of these risk factors in developed countries is likely driven by increased consumption of food consisting of high amounts of saturated fat, refined carbohydrates and sugars, and low levels of fibre, unsaturated fats, and antioxidants (Cordain et al., 2005). According to data of the CDPC of Latvia from 2018, $34.6 \%$ of persons aged 15 to 74 were overweight and $24.1 \%$ were obese (CDPC of Latvia, 2018).

The COVID-19 pandemic has a significant impact on the economic situation. Restrictions had a direct impact on employment and heightened the risk of food insecurity for millions due to lockdown and border restrictions (Hobbs, 2020). People in Latvia were also affected by job loss, for some only temporary.

The goal of this study was to identify the most fragile groups of the population regarding nutrition during the restrictions caused by the COVID-19 pandemic. This study was a part of the International Sexual Health and Reproductive Health Survey (I-SHARE) carried out in Latvia as a component of the National Research Programme project "Impact of COVID-19 on Health Care System and Public Health in Latvia; Ways in Preparing Health Sector for Future Epidemics".

\section{MATERIALS AND METHODS}

This study was carried out from 26 July to 3 September 2020. An online cross-sectional survey was developed for use in 33 countries as part of the I-SHARE study (Michielsen, 2020). It was centrally programmed as a selfadministered online survey using Open Data Kit software (version 1.16). The survey could be completed through smartphones, tablets, or computers. The study in Latvia was approved by the Ethical Committee of Rìga Stradiňš University (No. 6-1/06/25 from 28 May 2020). It was translated into Latvian and Russian, and the link to an online survey in both languages was distributed on social networks and in cooperation with non-governmental organisations.

The inclusion criteria were persons 18 years of age and living in Latvia, which was clarified automatically before the continuation of the questionnaire. The respondents' place of residence, age group, economic situation, as well as selfassessment of their mental health during the restrictions were taken into account when analysing the results, in order to identify the most fragile groups whose food availability and choice was affected by COVID-19 pandemic restrictions.

Standard fraud protection methods, including CAPTCHA and a measure to prevent more than one response from a single IP address, were included. Socio-demographic data were summarised using descriptive statistics and crosstabulation. Non-parametric tests were used in the analysis (Chi-Square test, Fisher exact test). Data were summarised and analysed using MS Excel and IBM SPSS 26.0. The results were considered as statistically significant if $p<0.05$.

A total of 1173 Latvian citizens, aged 18 to 68 , filled out an online survey. There was a predominance of women in the completed questionnaires $-82.4 \%$ of responders were women, $17.4 \%$ men, and $0.3 \%$ identified themselves as other sex. $83.2 \%$ filled out the survey in Latvian, $16.8 \%$ in Russian. $24.5 \%$ of responders were in the age group from 18 to 24 years, $35.3 \%$ were aged 25 to 32 years, $18.2 \%$ were aged 33 to $39,11.9 \%$ were 40 to 47 years old, $5.6 \%$ were 48 to 54 years old and $4.5 \%$ were older than 54 years. Dominantly, $63 \%$ of responders lived in Riga, the capital of Latvia, and others were from smaller cities.

\section{RESULTS}

Responders were asked if in times of COVID-19 pandemic restrictions their employment status changed. For almost a half or $48.8 \%$ there was no change in their employment status. Some worked from home: $8.4 \%$ fully and $8.9 \%$ partly. $2.9 \%$ lost jobs because of the COVID-19 pandemic and an additional $4.6 \%$ were temporarily unemployed. For $64.9 \%$ responders, the economic situation during COVID19 restrictions stayed the same, for $7.3 \%$ improved and for $27.8 \%$ responders it became worse. $24.9 \%$ noted partial loss of income, and $3.3 \%$ suffered total loss of income because of the COVID-19 pandemic.

$15.3 \%$ of respondents noted that they were worried about not having enough food during COVID-19 restrictions, but most respondents $(74.8 \%)$ were not worried. There was no statistically significant association between age or place of residence and worries to not have enough food. Households whose economic situation became worse more often were worried about not having enough food, in comparison with households whose economic situation did not change or improve (Table 1).

Table 1. Association between household economic situation, place of residence, age group and worries to not have enough food

\begin{tabular}{l|c|c|c|c}
\hline \multirow{2}{*}{$\begin{array}{c}\text { Economic situation in } \\
\text { household }\end{array}$} & No & $\begin{array}{c}\text { Yes, but less than } \\
\text { before }\end{array}$ & $\begin{array}{c}\text { Yes, but not more than } \\
\text { before }\end{array}$ & $\begin{array}{c}\text { Yes, more than } \\
\text { before }\end{array}$ \\
\cline { 2 - 5 } & $\begin{array}{c}\text { Pearson Chi-Square } \\
\text { test }\end{array}$ & $9.0 \%(29)$ & $25.2 \%(81)$ \\
\hline Became worse & $61.5 \%(198)$ & $4.3 \%(14)$ & $4.5 \%(34)$ & $11.4 \%(86)$ \\
Stayed the same & $79.5 \%(598)$ & $4.5 \%(34)$ & $1.2 \%(1)$ & $13.1 \%(11)$ \\
Improved & $82.1 \%(69)$ & $3.6 \%(3)$ & & $p=0.792$ \\
Place of residence & & & & \\
Age group & & & &
\end{tabular}


$9 \%$ of responders were not able to eat preferred food because of restrictions, an additional $3.2 \%$ noted an inability to obtain the preferred food even before restrictions, and $83.9 \%$ had no problems getting preferred food. Those whose economic situation did not change or became worse more often did not get preferred foods compared with those whose economic situation improved $(p<0.001)$. No association was found between place of residence or age group with preferred food (Table 2).

A significant association was noted between the age group and consumption of food because of reduced food availability $(p=0.001) .6 .4 \%$ of persons aged 40 to 47 and $6.1 \%$ of persons aged 48 to 54 years ate less in the period of COVID-19 restrictions. In comparison, only $0.7 \%$ of persons aged 25 to 32 years noted the need to eat less. No association was observed between place of residence and reduced food availability. Households in which the economic situation became worse ate less compared with households where the economic situation stayed the same $(p=0.001)$ (Table 3).

Significant differences between age groups were observed for the case when food stocks were empty with no way to get more food. Young people less often experienced this: $0.7 \%$ of persons aged 18 to 24 and $0.7 \%$ of those aged 25 to 32 years, compared with $5 \%$ of persons aged 40 to 47 and $7.6 \%$ of those aged 48 to 54 years, $p<0.001$. Also, households in which the economic situation became worse more often noted that their food stocks were empty with no way to procure more food, compared with households where the economic situation stayed the same $(p=0.001)$ (Table 4). No association was noted between place of residence and empty food stocks $(p=0.430)$.

Almost half of respondents noted that they increased food consumption during the period of restrictions: $39.4 \%$ a bit and $9.9 \%$ a lot. A significant association was noted between persons aged 18 to 24 years, who significantly increased food consumption, and persons aged 25 to 32 years and over 54 years, who did not increase or slightly increased food consumption $(p=0.003)$. A statistically significant association was observed between the economic situation in the household and food consumption during the restrictions - households, whose economic situation stayed the same or became worse, more often did not increase food consumption $(p=0.015)$ (Table 5). No association was noted

Table 2. Association between household economic situation, place of residence, age group and ability to eat preferred food

\begin{tabular}{|c|c|c|c|c|c|}
\hline \multirow{2}{*}{$\begin{array}{c}\text { Economic situation in } \\
\text { household }\end{array}$} & \multicolumn{4}{|c|}{ Changes in ability to eat preferred food } & \multirow[b]{2}{*}{$\begin{array}{c}\text { Pearson Chi-Square } \\
\text { test }\end{array}$} \\
\hline & No changes & $\begin{array}{c}\text { Yes, but less than } \\
\text { before }\end{array}$ & $\begin{array}{l}\text { Yes, but not more than } \\
\text { before }\end{array}$ & $\begin{array}{l}\text { Yes, more than } \\
\text { before }\end{array}$ & \\
\hline Became worse & $73.3 \%(236)$ & $5.9 \%(19)$ & $6.2 \%(20)$ & $14.6 \%(47)$ & $p<0.001$ \\
\hline Stayed the same & $89.2 \%(671)$ & $1.7 \%(13)$ & $2.1 \%(16)$ & $6.9 \%(52)$ & \\
\hline Improved & $88.1 \%(981)$ & $4.8 \%(36)$ & $1.2 \%(37)$ & $6.0 \%(104)$ & \\
\hline Place of residence & & & & & $p=0.085$ \\
\hline Age group & & & & & $p=0.442$ \\
\hline
\end{tabular}

Table 3. Association between household economic situation, place of residence, age group and eating less

\begin{tabular}{|c|c|c|c|c|c|}
\hline \multirow{2}{*}{$\begin{array}{c}\text { Economic situation in } \\
\text { household }\end{array}$} & \multicolumn{4}{|c|}{ Eating less because there was not enough food } & \multirow[b]{2}{*}{$\begin{array}{c}\text { Fisher's exact } \\
\text { test }\end{array}$} \\
\hline & No & $\begin{array}{c}\text { Yes, but less than } \\
\text { before }\end{array}$ & $\begin{array}{l}\text { Yes, but not more than } \\
\text { before }\end{array}$ & $\begin{array}{c}\text { Yes, more than } \\
\text { before }\end{array}$ & \\
\hline Became worse & $89.4 \%(286)$ & $2.5 \%(8)$ & $1.3 \%(4)$ & $6.9 \%(22)$ & $p<0.001$ \\
\hline Stayed the same & $98.5 \%(740)$ & $0.1 \%(1)$ & $0.9 \%(7)$ & $0.4 \%(3)$ & \\
\hline Improved & $96.4 \%(81)$ & $0.0 \%(0)$ & $1.2 \%(1)$ & $2.4 \%(2)$ & \\
\hline Place of residence & & & & & $p=0.111$ \\
\hline Age group & \multicolumn{4}{|c|}{$\begin{array}{c}\text { Persons aged } 40 \text { to } 47 \text { and } 48 \text { to } 54 \text { years more often experienced reduced food } \\
\text { availability ( } 6.4 \% \text { and } 6.1 \% \text { accordingly) in comparison with persons }\end{array}$} & $p<0.001$ \\
\hline
\end{tabular}
aged 25 to $32(0.7 \%)$ years

Table 4. Association between household economic situation, place of residence, age group and empty food stocks

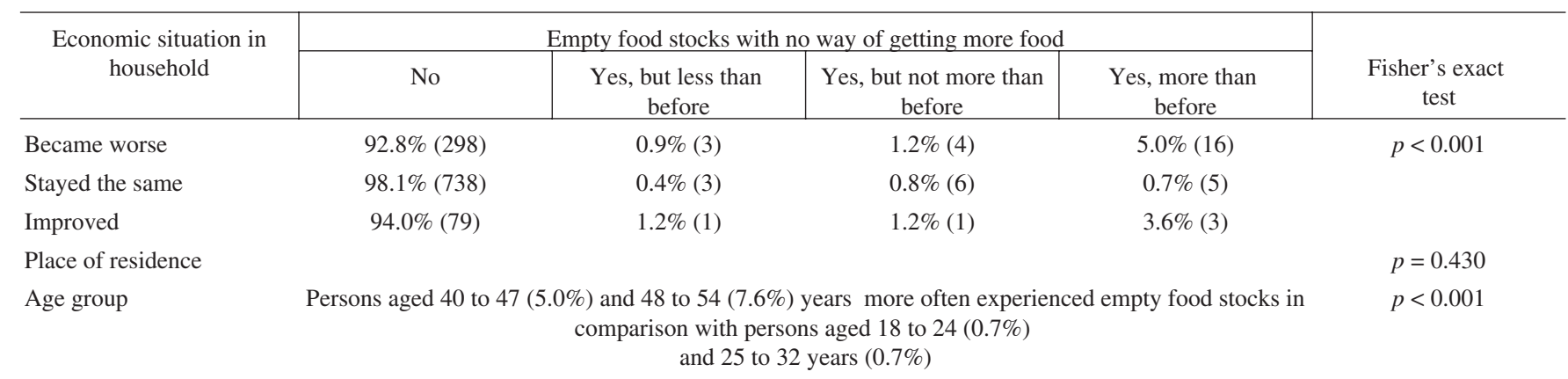


Table 5. Association between household economic situation, place of residence, age group and increase in food consumption

\begin{tabular}{|c|c|c|c|c|}
\hline \multirow{2}{*}{$\begin{array}{c}\text { Economic situation in } \\
\text { household }\end{array}$} & \multicolumn{3}{|c|}{ Increased consumption of food } & \multirow{2}{*}{$\begin{array}{c}\text { Pearson } \\
\text { Chi-Square test }\end{array}$} \\
\hline & No & Yes, a bit & Yes, a lot & \\
\hline Became worse & $48.0 \%(154)$ & $39.3 \%(126)$ & $12.8 \%(41)$ & $p<0.015$ \\
\hline Improved & $36.9 \%(31)$ & $50.0 \%(42)$ & $13.1 \%(11)$ & \\
\hline Place of residence & & & & $p=0.371$ \\
\hline Age group & \multicolumn{3}{|c|}{$\begin{array}{l}\text { Persons aged } 18 \text { to } 24(14.4 \%) \text { years more often increased food consumption in comparison with persons } \\
\text { aged } 25 \text { to } 32(8.4 \%) \text { years and persons older than } 54 \text { years }(0.0 \%)\end{array}$} & $p<0.003$ \\
\hline
\end{tabular}

Table 6. Association between household economic situation, place of residence, age group and increased consumption of food of low nutritional value

\begin{tabular}{|c|c|c|c|c|}
\hline \multirow{2}{*}{$\begin{array}{c}\text { Economic situation in } \\
\text { household }\end{array}$} & \multicolumn{3}{|c|}{ Increased consumption of food of low nutritional value } & \multirow{2}{*}{$\begin{array}{c}\text { Pearson } \\
\text { Chi-Square test }\end{array}$} \\
\hline & No & Yes, a bit & Yes, a lot & \\
\hline Became worse & $73.2 \%(235)$ & $20.6 \%(66)$ & $6.2 \%(20)$ & $p<0.001$ \\
\hline Stayed the same & $86.4 \%(650)$ & $13.0 \%(98)$ & $0.5 \%(4)$ & \\
\hline Improved & $79.8 \%(67)$ & $19.0 \%(16)$ & $1.2 \%(1)$ & \\
\hline Place of residence & & & & $p=0.279$ \\
\hline Age group & \multicolumn{3}{|c|}{$\begin{array}{c}3.8 \% \text { of persons aged } 33 \text { to } 39 \text { years significantly increased consumption of food of low nutritional value in } \\
\text { comparison with } 0.5 \% \text { of persons aged } 25 \text { to } 32 \text { years. Nevertheless, both groups increased food consump- } \\
\text { tion of low nutritional value, } 24.3 \% \text { and } 15.9 \% \text { accordingly. }\end{array}$} & $p<0.018$ \\
\hline
\end{tabular}

between place of residence and increased food consumption $(p=0.371)$.

In times of COVID-19 pandemic restrictions, $17.7 \%$ increased consumption of food of low nutritional value, especially among younger people - $15.9 \%$ of persons aged 25 to 32 years and $24.3 \%$ of people aged 33 to 39 years ( $p=$ $0.018)$. No association was noted between place of residence and consumption of food of low nutritional value ( $p=$ 0.279). Households whose economic situation became worse more often ate food of low nutritional value, in comparison with households whose economic situation did not change $(p=0.001)$ (Table 6).

Respondents self-assessed their mental health on a scale from 1 to 5, where one meant poor and five - excellent. Significant correlation was observed between mental health assessment and food consumption during the COVID-19 restrictions, as crisis like the COVID-19 pandemic could cause mental health issues, which could affect food intake habits. Data showed that increased food consumption was less common in people with better mental health $(p<$ 0.001).

\section{DISCUSSION}

The study showed that restrictions implemented to limit the spread of COVID-19 had an influence on the socioeconomic situation and food choice and availability for certain groups of the population. The ability to eat a healthy diet is largely determined by one's access to affordable, healthy foods - a consequence of the conditions and environment in which one lives (Belanger, 2020). Households whose economic situation became worse more often did not have access to preferred foods, ate less and noted that their food stocks were empty during COVID-19 pandemic restrictions. Persons up to the age of 40 tended to increase food consumption and consumption of food of low nutritional value, while persons over 40 years more often noted reduced food availability and experienced empty food stocks. With additional research, it would be important to understand whether reduced food availability was mostly related to the deteriorating economic situation, or if there were additional restrictive factors.

Although a healthy diet during a global pandemic is crucial for maintaining immunity and health, one-third of the study participants increased consumption of foods of low nutritional value. This is a worrying signal, especially in combination with the fact that almost half of respondents increased food consumption in general, which could lead to obesity and other associated health conditions. Obesity may be a common denominator of associated coexisting conditions and underlying socioeconomic factors linked to worse outcomes from COVID-19 (Belanger, 2020). Individuals with obesity have an increased risk of hospitalisation, increased need for intensive care and increased risk of death (Ryan, 2020; Sattar, 2020; Simonnet, 2020; Yang, 2020; Williamson, 2020). In further studies, additional factors such as BMI changes, activity level, calorie balance and others should be included for a more accurate evaluation of the effects of increased food intake on overall health.

The nonmedical factors and conditions that influence health include economic stability, access to nutritious food, social and community context, and access to health services (Daniel, 2018). Most of the respondents continued their jobs, but one-third noted that their household economic situation became worse, which was associated with difficulty of procuring food. Measures to help such households obtain the food 
they need should be implemented in the event of such crises.

As COVID-19 restrictions included limited access to faceto-face meetings, the study was implemented fully online. Although the response rate was sufficient, certain groups of the population were difficult to reach. We found that men, older people and people living outside the capital of Latvia less often participated in the study. It would be important to implement special measures to reach out to these groups in further studies.

\section{CONCLUSIONS}

COVID-19 has influenced the economic situation and food choice and availability. The economic situation became worse for one-third of respondents, although most of them continued to work. For most respondents, food availability was not reduced. Almost a half of the respondents increased food consumption during the COVID-19 pandemic restrictions, and in addition, on-fifth increased consumption of food of low nutritional value. The most fragile groups regarding nutrition in times of the COVID-19 restrictions were households whose economic situation became worse and experienced changes in food availability and choice, younger persons who increased food consumption in general together with consumption of food of low nutritional value, and persons aged 40 to 54 years who more often experienced reduced food availability and empty food stocks. Increased food consumption was less common among people with better mental health.

\section{ACKNOWLEDGEMENTS}

We would like to thank the I-SHARE Consortium for cooperation and to those that have participated in the online survey. The study was financed and carried out as part of the National Research Programme project "Impact of COVID-19 on Health Care System and Public Health in Latvia; Ways in Preparing Health Sector for Future Epidemics" (Project No. VPP-COVID-2020/1-0011).

\section{REFERENCES}

Belanger, M. J., Hill, M. A. Angelidi, A. M., Dalamaga, M., Sowers, J. R., Mantzoros, C. S. (2020). COVID-19 and disparities in nutrition and obesity. New Engl. J. Med., 383, e69.

Butler, M. J., Barrientos, R. M. (2020). The impact of nutrition on COVID-19 susceptibility and long-term consequences. Brain Behav. Immun., 87, 53-54.
CDPC of Latvia. Health Behaviour among Latvian Adult Population (2018). https://www.spkc.gov.lv/lv/veselibu-ietekmejoso-paradumu-petijumi/latv ijas-iedzivotaju-veselibu-ietekmejoso-paradumu-petijums-2018-i-un-ii-d ala.pdf/latvijas-iedzivotaju-veselibu-ietekmejoso-paradumu-petijums-201 8-i-un-ii-dala.pdf (accessed 31.10. 2021).

Cordain, L., Eaton, S. B., Sebastian, A., Mann, N., Lindeberg, S., Watkins, B. A., O'Keefe, J. H., Brand-Miller, J. (2005). Origins and evolution of the Western diet: Health implications for the $21^{\text {st }}$ century. Amer. J. Clin. Nutr., 81, 341-354.

COVID-19 statistics in Latvia until 3 September 2020. Data from the Centre for Disease Prevention and Control of Latvia. https://infogram.com/c19-izplatiba-latvija-2020-1h7v4pzlzlnj6k0 (accessed 01.01.2021).

Daniel, H., Bornstein, S. S, Kane, G. C. (2018). Addressing social determinants to improve patient care and promote health equity: An American College of Physicians position paper. Ann. Internal Med., 168, 577-578.

Dietz, W., Santos-Burgoa, C. (2020). Obesity and its implications for COVID-19 mortality. Obesity (Silver Spring), 28, 1005-1005.

Hobbs, J. E. (2020). Food supply chains during the COVID-19 pandemic. Canad. J. Agricult. Econ., 68, 171-176.

Johns Hopkins University CSSE COVID-19 data. Daily new confirmed COVID-19 cases per million people.

https://ourworldindata.org/coronavirus\#acknowledgements (accessed 1 January 2021).

Michielsen, K., Larrson, E. C., Kågesten, A., Erausquin, J. T., Griffin, S., Velde, Sarah van de, Tucker, J. D. (2020). International Sexual Health and Reproductive Health (I-SHARE) Survey during COVID-19: Study protocol for online national surveys and global comparative analyses. Sexually Transmit. Infect., 97 (2), 88-92.

Ryan, D. H., Ravussin, E., Heymsfield, S. (2020). COVID 19 and the patient with obesity — the editors speak out. Obesity (Silver Spring), 28 (5), 847.

Sattar, N., McInnes, I. B., McMurray, J. J. V. (2020). Obesity a risk factor for severe COVID-19 infection: Multiple potential mechanisms. Circulation, 142 (1), 4-6. DOI: 10.1161/CIRCULATIONAHA.120.047659.

https://pubmed.ncbi.nlm.nih.gov/ (accessed 31 December 2020).

Simonnet, A., Chetboun, M., Poissy, J., Raverdy, V., Noulette, J., Duhamel, A., Labreuche, J., Mathieu, D., Pattou, F., Jourdain, M. (2020). High prevalence of obesity in severe acute respiratory syndrome coronavirus-2 (SARS-CoV-2) requiring invasive mechanical ventilation. Obesity (Silver Spring), 28 (7), 1195-1199.

The World Health Organization. Coronavirus disease (COVID-19) situation report, March 11th. www.who.int/docs/default-source/coronaviruse/situation-reports/20200311-sitrep-51-covid-19.pdf?sfvrsn=1ba62e57_10 (accessed 01.01. 2021).

Williamson, E. J., Walker, A. J., Bhaskaran, K., Bacon, S., Bates, C., Morton, C. E., Curtis, H. J., Mehrkar, A., Evans, D., Inglesby, P., et al. (2020). Factors associated with COVID-19-related death using OpenSAFELY. Nature, 584, 430-436.

Yang, J, Hu, J, Zhu, C. (2021). Obesity aggravates COVID-19: A systematic review and meta-analysis. J. Med. Virol., 93 (1), 257-261. 


\section{SOCIĀLEKONOMISKO FAKTORU UN PĀRTIKAS IZVĒLES UN PIEEJAMĪBAS IZMAIṆAS COVID-19 IEROBEŽOJUMU LAIKĀ LATVIJĀ}

Covid-19 epidēmija ietekmējusi pasaules iedzīvotāju ikdienu. Šis pētījums bija daḷa no pētījuma International Sexual Health and Reproductive Health Survey (I-SHARE), kas tika realizēts Latvijā kā dą̣a no Valsts pētījumu programmas projekta "COVID-19 epidēmijas ietekme uz veselības aprūpes sistēmu un sabiedrības veselību Latvijā; veselības nozares gatavības nākotnes epidēmijām stiprināšana". Pētījuma mērḳis bija noskaidrot tās Latvijā dzīvojošās iedzīvotāju grupas, kuru pārtikas izvēli un pieejamību visvairāk ietekmēja ierobežojumi, kas saistīti ar Covid-19 izplatības mazināšanu. Starptautiski validēta šḳērsgriezuma tipa tiešsaistes anketa tika izplatīta sociālajos tīklos no 2020. gada 26. jūlija līdz 3. septembrim, to brīvprātīgi varēja aizpildīt vismaz 18 gadus sasnieguši Latvijas iedzīvotāji latviešu un krievu valodās. Dati tika analizēti ar MS Excel un IBM SPSS Statistics 26.0. Tika saṇemtas 1173 atbildes no personām, kas bija vecumā no 18 līdz 68 gadiem. Nodarbinātība ierobežojumu laikā lielākajai daḷai respondentu nemainījās, daḷa darbu turpināja attālināti, daḷai darbu nācās īslaicīgi pārtraukt. Trešdą̧a no respondentiem atzīmēja mājsaimniecības ekonomiskās situācijas pasliktināšanos. Gandrīz 30\% mājsaimniecību, kurās ekonomiskā situācija ierobežojumu laikā pasliktinājās, biežāk uztraucās par pārtikas nepietiekamību, nevarēja iegūt iecienīto pārtiku, samazināja uzņemtās pārtikas apjomu, biežāk uzṇēma pārtiku ar zemu uzturvērtību, kā arī viņu pārtikas krājumi biežāk bija tukši bez iespējas tos papildināt. Cilvēki vecumā no 40 līdz 54 gadiem biežāk atzīmēja ierobežotu pieeju iecienītajai pārtikai ierastajā apjomā. Gandrīz puse no visiem respondentiem norādīja, ka Covid-19 ierobežojumu laikā palielināja pārtikas uzņemšanu, īpaši jaunāki cilvēki. Viena piektdaḷa no respondentiem palielināja pārtikas ar zemu uzturvērtību uzṇemšanu, sevišḳi vecuma grupā no 33 līdz 39 gadiem. Pastiprināta pārtikas uzṇemšana retāk tika novērota starp cilvēkiem, kas savu mentālo veselību vērtēja kā labu, ḷoti labu vai izcilu. Pētījumā iegūtie dati norāda uz nepieciešamību plašāk pētīt Covid-19 ierobežojumu ietekmi uz uztura paradumiem pieaugušo populācijā Latvijā. 